\title{
DESENVOLVIMENTO DE EMULSÕES CONTENDO PRINCÍPIOS ATIVOS ANTIENVELHECIMENTO E DETERMINAÇÃO IN VITRO DO FATOR DE PROTEÇÃO SOLAR
}

\author{
DEVELOPMENT OF EMULSIONS CONTAINING ANTI-AGING \\ ACTIVES IN VITRO DETERMINATION OF THE SOLAR \\ PROTECTION FACTOR
}

\author{
Benedetti, V. P. ${ }^{1}$, Carli, R. B. G. ${ }^{1}$, Silva, D. R. ${ }^{1}$, Cesaro, M. C. ${ }^{1}$, Silva, A. C. P. , Meotti, F. \\ L. 1 \\ Afiliações: 1- Universidade Paranaense, campus de Francisco Beltrão. \\ Endereço do autor de correspondência Av. Júlio Assis Cavalheiro, 2000, Centro, Francisco Beltrão, Paraná, Brasil. CEP: 85601-000. \\ volmir@prof.unipar.br
}

\section{Resumo}

Modificações nas características da pele no período do envelhecimento são inevitáveis, sendo influenciadas por fatores intrínsecos, conhecidos como 'envelhecimento natural', e fatores extrínsecos, causados por fatores ambientais, como a radiação solar. No presente estudo, foram desenvolvidas formulações semissólidas fotoprotetoras com os ativos antienvelhecimento (Adenin ${ }^{\circledR}$, Biolumen ${ }^{\circledR}$ Firm e Lipossomas de Coenzima Q10 ${ }^{\circledR}$ ). Foi determinado o fator de proteção solar in vitro e avaliada a estabilidade das diferentes formulações. As emulsões contendo os filtros metoxicinamato de octila associado à benzofenona3 obtiveram FPS de 27,45, e com os ativos antienvelhecimento Adenin ${ }^{\circledR}$, Biolumen ${ }^{\circledR}$ Firm e Lipossomas de Coenzima $Q 10^{\circledR}, 24,31,24,90$ e 33,17, respectivamente. Ao produzir as formulações contendo o filtro solar hidrossolúvel UVA-UVB, o resultado na determinação do FPS foi de 12,48. Na presença dos ativos antienvelhecimento, os resultados apresentaram um decréscimo. No estudo de estabilidade prévia, as formulações contendo os filtros metoxicinamato de octila e benzofenona3, juntamente com os ativos antienvelhecimento, mostraram-se mais estáveis quando comparadas às formulações com o filtro solar hidrossolúvel UVA-UVB na presença dos ativos antienvelhecimento. Sendo assim, os filtros metoxicinamato de octila e benzofenona 3 podem ser associados a estes ativos antienvelhecimento sem causar alterações significativas em seu FPS e sua estabilidade.

Palavras-chave: Ativos Antienvelhecimento; Envelhecimento Extrínseco; Fator de Proteção Solar in vitro; Filtro Solar.

\section{Abstract}

Modifications in skin characteristics during aging are inevitable, and are influenced by intrinsic factors, known as 'natural aging', and extrinsicfactors, caused by environmental factors, such as solar radiation.In the present study, semisolid formulations containing photoprotectors were developed with different aging actives (Adenin ${ }^{\circledR}$, Biolumen ${ }^{\circledR}$ Firm, and Coenzyme $\mathbf{Q 1 0}{ }^{\circledR}$ Liposomes). The solar protection factor was determined in vitro, and the stability of the different formulations was evaluated. The emulsions containing the filters octylmethoxycinnamate and benzophenone-3 had an FPS of 27.45, while those including the anti-aging actives Adenin ${ }^{\circledR}$, Biolumen ${ }^{\circledR}$ Firm, and Coenzyme $\mathbf{Q 1 0}^{\circledR}$ Liposomes presented FPS of 24.31, 24.90, and 33.17, respectively. When producing the formulations containing the hydrosoluble UVA-UVB sunscreen, the obtained FPS determination was of 12.48. In the presence of the anti-aging actives, the results revealed a decrease. Meanwhile, when analyzing primary stability, the formulations including the filters octylmethoxycinnamate and benzophenone-3, as well as the anti-aging actives, showed to be more stable when compared with those containing hydrosolubleUVA-UVB sunscreen in the presence of the anti-aging actives. Thus, the filters octylmethoxycinnamate and benzophenone-3 can be associated with these anti-aging actives without significant differences in SPF and stability.

Keywords: Anti-Aging Active; Extrinsic Aging; Sun Protection Factor in vitro; Sunscreen. 


\section{Introduction}

Aging constitutes a natural process caused by intrinsic and extrinsic factors. Intrinsic aging is considered inevitable since, over time, the skin changes, reducing collagen and estrogen fibers, becoming more flaccid, thin, and sensitive. It also becomes more prone to the appearance of wrinkles and spots. Extrinsic aging, in turn, depends on the relationship between sun exposure and skin phototype, characterized by photoaging. ${ }^{1,2}$

UVA and UVB rays present in solar radiation can cause premature aging and loss of hyperpigmentation. UVA rays originate photodermatoses, which favor skin aging and the appearance of spots. UVB rays, in turn, are those that stimulate tanning and cause sunburn. ${ }^{3}$

In this context, photoprotection plays a considerably significant role. Preventing the appearance of skin damage, such as aging, deep wrinkling, skin cancer, and photodermatoses, are attitudes that can be carried outby the use of topical sunscreen, for example. ${ }^{4}$ The efficiency of sunscreen is measured by the sun protection factor, which can be determined in vitro and in vivo.

The purpose of using sunscreen is decrease the intensity of radiation before it penetrates the skin through photoprotection effects. Sunscreen are divided into two types: organic, such as benzophenone-3, octylmethoxycinnamate, and water-soluble UVA and UVB filters, and inorganic, including titanium dioxide and zinc oxide. Organic sunscreen present aromatic compounds with carboxylic groups that preserve the skin by absorbing high-energy ultraviolet radiation, transforming it into harmless energy (not prejudicial to humans). There are several types of organic sunscreen, each one has specific physical and chemical characteristics. Benzophenone-3 (2-hydroxy-4methoxy-benzophenone) provides good UVB and UVA protection, excellent chemical stability, and its concentration for topical application is up to $5.0 \% .^{3}$

Octylmethoxycinnamate (2-ethylhexyl 4-methoxycinnamate), whose concentration can be used up to $8.5 \%$, absorbs UVB radiation well, but little UVA radiation. When associated with benzophenone-3, its photoprotective effect increases. ${ }^{5}$ 
The UVA and UVB water-soluble

filter (2-phenylbenzimidazole-5-sulfonic acid, 2-hydroxy-4-methoxybenzophenone-5-sulfonic acid, propandiol-1,2, and water) retains excellent compatibility with any skin type. It is easily produced and handledand can be used in concentrations up to $20 \%$. $^{6}$

Inorganic sunscreen contains metal oxides in their formulation. They are composed of particles that present the size of the radiation to be dispersed, and their effectiveness is determined by the order which the particles are found. This type of filter is substantially safe and effective due its low irritability potential and is mainly used in individuals with more sensitive skin. ${ }^{7}$

These products are widely offered in the current market, either in the form of gels, lotions, sticks, or aerosols. Their formulation may include, in addition to sunscreen, agents with secondary functions such as antioxidants, anti-aging actives, oil control agents, and pigments, among others. ${ }^{4}$

The demand for anti-aging gents in sunscreen has increased considerably, allowing people to age healthily, postponing changes caused by time on the skin. ${ }^{7}$ In this context, several products may be associated with sunscreen, such as $\operatorname{Adenin}^{\circledR}$, Biolumen ${ }^{\circledR}$ Firm, and Coenzyme Q10 ${ }^{\circledR}$ Liposomes. ${ }^{8}$

Adenin $^{\circledR}$, can be used in concentrations up to $0.1 \%$, is a synthetic plant hormone that, when in contact with human skin, delays or reverses age-related cellular alterations. ${ }^{9}$

Biolumen ${ }^{\circledR}$ Firm has in composition amino acids derived from yeast and polyphenols coated with a tricalcium phosphate substrate. This anti-aging treatment utilizes photodynamic therapy through the use of UV light, which stimulates the activity of fibroblasts, promoting the reduction of wrinkles and cell repair, as well as increasing skin elasticity. It can be used in concentrations up to $5 \% .^{10}$

Coenzyme Q10 ${ }^{\circledR}$ liposomes have high skinpenetration capacity and elevated moisture retention and are indicated in the improvement of skin resistance. These actives contain antioxidant molecules in their formula that decrease the concentration of free radicals and their action on cells. Additionally, they may be used at concentrations of $0.5 \%$ to $5 \% .^{11}$

The incorporation of anti-aging actives in photoprotective formulations may alter the value of the sun protection factor of the Polawax ${ }^{\circledR}$ nonionic base emulsion. Therefore, 
tests were performed to ensure the value of the product's sun protection. In the present study, photoprotective semi-solid formulations containing different anti-aging actives were developed in order to determine the sun protection factor in vitro, as well as predict their stability.

\section{Methods}

This study was developed in the

Laboratory of Pharmacotechnics in University of Paraná (UNIPAR), located at the Francisco Beltrão University Unit, in Paraná, Brazil.

The used materials consisted of: benzophenone-3 (Galena-lot: 1508018201), octylmethoxycinnamate (Fagron - lot: 328976), water-soluble UVA-UVB filter (Mapric - lot: PROD018028), $\quad$ Adenin $^{\circledR}($ Galena $\quad-\quad$ lot: 14060113), Biolumen ${ }^{\circledR}$ Firm (Galena lot:1504020201), and Coenzyme Q10 ${ }^{\circledR}$ Liposomes (Mapric - lot: PROD018520).

\section{EMULSION DEVELOPMENT}

Formulations development, a nonionic base was selected, which is an improved combination of plant-based stabilizers and emulsifiers used for skincare lotions and creams. The utilized formula is described in Table 1.

Table 1. Description of the components of the nonionic base $\left(\right.$ Polawax $\left.^{\circledR}\right)$.

\begin{tabular}{ccc}
\hline Phase & Raw materials & Quantity \\
\hline & Polawax & $12.0 \mathrm{~g}$ \\
$\mathrm{~A}$ & Cetoestearilic & $1.5 \mathrm{~g}$ \\
& alcohol & \\
& Mineral Oil & $5.0 \mathrm{~mL}$ \\
& Propylparaben & $0.1 \mathrm{~g}$ \\
\hline & Propylene & $5.0 \mathrm{~mL}$ \\
& glycol & \\
& EDTA & $0.1 \mathrm{~g}$ \\
$\mathrm{~B}$ & Methylparaben & $0.1 \mathrm{~g}$ \\
& QPS distilled & $100 \mathrm{~mL}$ \\
& water & \\
\hline $\mathrm{g}=$ Grams, $\mathrm{mL}=$ Milliliters
\end{tabular}

The emulsions were prepared by heating the components of the oil phase and the aqueous phase on $752 \mathrm{~A}$ magnetic heating agitator (Fisatom). The components of eachphase were separated into beakers for heating, after which the two were removed as soon as they reached temperatures of $70^{\circ} \mathrm{C}$. Next, aqueous phase was poured over the oil phase and kept under constant stirring until reaching $40^{\circ} \mathrm{C}$, after which the nonionic base was reserved.

Following complete cooling, the nonionic base was divided into two parts. In the first part, 5.0\% of benzophenone-3 was added, together with $8.5 \%$ octylmethoxycinnamate. In the second part, $17 \%$ of water-soluble UVAUVB filter was added. Afterward, the two 
emulsions were again divided into two parts. In one part of each emulsion, the sun protection factor (SPF) was determined, and in the other, three divisions were carried out. Since three anti-aging actives were tested (Adenin ${ }^{\circledR}$, Coenzyme $\quad$ Q10 ${ }^{\circledR}$ Liposomes, $\quad$ and Biolumen ${ }^{\circledR}$ Firm), they were incorporated into each part of the division, totaling eight formulations, that were separated in triplicate, each weighing 10 grams. The formulations were then packaged in plastic tubes and underwent SPF determination.

\section{SUN PROTECTION FACTOR}

\section{DETERMINATION}

In order to determine the sun protection factor (SPF) of the emulsions, in vitro spectrophotometric method described by Mansur et al. (1986) ${ }^{12}$ and cited by Alves et al. $(2010)^{13}$ was employed.

From each emulsion, 0.5 grams was weighed and diluted in $96^{\circ} \mathrm{GL}$ ethyl alcohol, then transferred to $25 \mathrm{~mL}$ volumetric flask, followed by the addition of sufficient ethyl alcohol to complete the volume. A total of 0.1 $\mathrm{mL}$ was removed from previous dilution, and the volume was filled with ethyl alcohol to 25
$\mathrm{mL}$ in another volumetric flask, obtaining a concentration of $0.2 \mu \mathrm{L} / \mathrm{mL}$. Subsequently, the absorbances were read on a UV-1601 spectrophotometer (Shimadzu) at wavelengths of 290 to $320 \mathrm{~nm}$ at $5 \mathrm{~nm}$ intervals. After emulsion reading, the SPF of each one was calculated following Equation 1.

\section{Equation 1. SPF $=\mathrm{CF} \cdot \sum_{290^{*}}^{320} E E(\lambda) \cdot A b s(\lambda)$}

In this equation, $\mathrm{CF}$ is the correction factor equal to $10 ; \mathrm{EE}(\lambda)$ constitutes the erythematogenic effect of solar radiation at each wavelength $\lambda$; i ( $\lambda$ ) comprises the intensity of light at wavelength $\lambda$, and $\operatorname{Abs}(\lambda)$ is the spectrophotometric reading of the sample absorbance in each wavelength. The control used in the analyses was $96^{\circ} \mathrm{GL}$ ethyl alcohol, and the $\operatorname{EE}(\lambda) \times \mathrm{I}(\lambda)$ values for each wavelength are shown in Table 2.

Table 2. Values employed in the SPF determination calculation.

\begin{tabular}{cc}
\hline$\lambda(\mathrm{nm})$ & $\mathrm{EE}(\lambda) \times \mathrm{I}(\lambda)$ \\
\hline 290 & 0.0150 \\
295 & 0.0817 \\
300 & 0.2874 \\
305 & 0.3278 \\
310 & 0.1864 \\
315 & 0.0839 \\
320 & 0.0180 \\
$\lambda=\frac{\text { Wavelength }-\mathrm{nm} ; \mathrm{EE}(\lambda)=\text { Erythematogenic effect; I }(\lambda)}{\text { Absorbance }}$
\end{tabular}


PRIMARY EMULSION STABILITY

\section{ASSESSMENT}

After determining the SPF of formulations, they were submitted to primary stability analysis (ice-thaw cycle). In this present study, the emulsions were stored for 24 hours in freezer at $-5 \pm 2{ }^{\circ} \mathrm{Cand} 24$ hours in an oven at $45 \pm 2{ }^{\circ} \mathrm{C}$ for 15 days, aiming to accelerate possible reactions between the emulsion components. Organoleptic characteristics, mechanical stress, $\mathrm{pH}$, and spreadability were analyzed, and all tests were performed in triplicate. ${ }^{14}$

\section{ORGANOLEPTIC CHARACTERISTICS}

The organoleptic characteristics, aspect, color, and odor were visually analyzed in order to monitor and observe the homogeneity of the formulations, thus enabling to verify possible instabilities. $^{13}$

\section{MECHANICAL STRESS}

Approximately $2 \mathrm{~g}$ of each formulation was placed in test tubes and centrifuged in Centrifuga Baby ${ }^{\circledR}$ I centrifuge for 15 minutes at
$3000 \mathrm{rpm}$. The purpose of the test was to check if they presented sedimentation or phase separation. ${ }^{15}$

\section{PH DETERMINATION}

Prior to start the test, Tec 3-MP pH meter was calibrated with $\mathrm{pH} 7.0$ and $\mathrm{pH} 4.0$ buffer solutions. Next, $10 \%$ solution of each emulsion was prepared and read. ${ }^{16}$

\section{SPREADABILITY}

A circular glass mold plaque with a hole in the center was superimposed to glass support plaque that contained a sheet of graph paper in its interior. A small amount of sample was placed in the plaque's hole, while the surface was leveled with a spatula. Subsequently, the circular plaque was removed. A Petri dish was placed on the sample and, after one minute, the encompassed surface was calculated by two-position diameter, horizontally and vertically. ${ }^{17}$ Spreadability was calculated using Equation 2.

Equation 2.Si $=d^{2} \cdot \frac{\pi}{4}$ 
In this equation, $\mathrm{Si}$ constitutes the spreadability of the sample for weight (i), and (d) is the mean diameter (mm) squared.

\section{Results}

\section{SOLAR PROTECTION FACTOR}

\section{DETERMINATION}

The SPF was initially determined only regarding the base emulsion to establish value. After the addition of anti-aging actives, the SPF was again quantitated to see if they would enhance or decrease value. Tables 3 and 4 shows the results of the SPF determination in analyzed formulations.

Table 3. Results of the in vitro SPF determinations of the emulsions containing benzophenone-3 and octylmethoxycinnamate, and after the addition of the anti-aging actives.

\begin{tabular}{cc}
\hline Sunscreen & SPF \\
\hline BZ3 + OMC & $27.45 \pm 0.31$ \\
BZ3 + OMC + Adenin ${ }^{\circledR}$ & $24.31 \pm 0.67$ \\
BZ3 + OMC + & $33.17 \pm 1.21$ \\
Coenzyme Q10 ${ }^{\circledR}$ L. & \\
BZ3 + MCO + & $24.90 \pm 1.22$ \\
Biolumen ${ }^{\circledR}$ Firm & \\
\hline
\end{tabular}

BZ3 = Benzophenone- 3 ; OMC = Octylmethoxycinnamate; SPF = Sun protection fator
Table 4. Results of in vitro SPF determinations of the emulsions containing water-soluble sunscreen, and after addition of the anti-aging actives.

\begin{tabular}{cc}
\hline Sunscreen & SPF \\
\hline Water-sol. Filter & $12.48 \pm 0.42$ \\
Water-sol. Filter + & $6.69 \pm 0.17$ \\
Adenin ${ }^{\circledR}$ & \\
Water-sol. Filter + & $9.71 \pm 0.56$ \\
Coenyme Q10 ${ }^{\circledR}$ L. & \\
Water-sol. Filter + & $7.17 \pm 0.39$ \\
Biolumen ${ }^{\circledR}$ Firm & \\
\hline SPF = Sun protection fator &
\end{tabular}

According to Table 3, nonionic emulsion containing benzophenone-3, associated with octylmethoxycinnamate, obtained an SPF of 27.45, near SPF 30. However, a reduction in the results was observed after addition of the anti-aging actives $\operatorname{Adenin}^{\circledR}$ (24.31) and Biolumen ${ }^{\circledR}$ Firm (24.90). On the other hand, the Coenzyme Q10 ${ }^{\circledR}$ Liposomeactive enhanced the SPF value of the nonionic base emulsion, with SPF of 33.17.

\section{PRIMARY EMULSION STABILITY \\ ASSESSMENT}

All tests were performed in triplicate and at time zero (24 hours) after 15 days. The results obtained in primary stability assessment 
Table 5. Characteristics of the formulations containing benzophenone- $3+$ octylmethoxycinnamate and the anti-aging actives.

\begin{tabular}{|c|c|c|c|c|c|c|c|c|}
\hline \multirow{3}{*}{ Parameters } & \multicolumn{8}{|c|}{ Formulations } \\
\hline & \multicolumn{2}{|c|}{ Control } & \multicolumn{2}{|c|}{$\begin{array}{c}\text { Adenin }^{\circledR} \\
+\mathrm{BZ3}+\mathrm{OMC}\end{array}$} & \multicolumn{2}{|c|}{$\begin{array}{l}\text { Biolumen }^{\circledR} \text { Firm } \\
+ \text { BZ3 + OMC }\end{array}$} & \multicolumn{2}{|c|}{$\begin{array}{c}\text { Coenzyme Q10 }{ }^{\circledR} \mathrm{L} .+ \\
\text { BZ3 + OMC }\end{array}$} \\
\hline & $\mathrm{t}_{0}$ & ${ }^{\mathrm{t}} 15_{\mathrm{d}}$ & $\mathrm{t}_{0}$ & ${ }^{\mathrm{t}} 15_{\mathrm{d}}$ & $\mathrm{t}_{0}$ & ${ }^{\mathrm{t}} 15_{\mathrm{d}}$ & $\mathrm{t}_{0}$ & ${ }^{\mathrm{t}} 15_{\mathrm{d}}$ \\
\hline Color & $\mathrm{CO} / \mathrm{OP}$ & $\mathrm{CO} / \mathrm{OP}$ & $\mathrm{CO} / \mathrm{OP}$ & $\mathrm{CO} / \mathrm{OP}$ & $\mathrm{CO} / \mathrm{OP}$ & $\mathrm{CO} / \mathrm{OP}$ & $\mathrm{CO} / \mathrm{OP}$ & $\mathrm{CO} / \mathrm{OP}$ \\
\hline Odor & C & C & C & C & C & C & C & C \\
\hline Homogeneity & $\mathrm{C}$ & $\mathrm{C}$ & $\mathrm{C}$ & $\mathrm{C}$ & $\mathrm{C}$ & $\mathrm{C}$ & $\mathrm{C}$ & $\mathrm{C}$ \\
\hline Brightness & $\mathrm{C}$ & $\mathrm{C}$ & $\mathrm{C}$ & $\mathrm{C}$ & $\mathrm{C}$ & $\mathrm{C}$ & $\mathrm{C}$ & $\mathrm{C}$ \\
\hline $\mathrm{pH}$ & 5.69 & 6.07 & 5.69 & 6.02 & 7.60 & 7.88 & 5.92 & 5.60 \\
\hline $\begin{array}{l}\text { Spreadability } \\
\left(\mathrm{mm}^{2}\right)\end{array}$ & $\begin{array}{r}1.321 .67 \\
+105.12\end{array}$ & $\begin{array}{c}1.520 .28 \\
\pm \\
56.40\end{array}$ & $\begin{array}{r}1.499 .08 \\
\pm 117.72\end{array}$ & $\begin{array}{c}2.301 .88 \\
\pm \\
1.250 .15\end{array}$ & $\begin{array}{c}1.567 .38 \\
\pm \\
87.00\end{array}$ & $\begin{array}{r}2.146 .44 \\
\pm 687.86\end{array}$ & $\begin{array}{c}1.451 .98 \\
\pm \\
55.12\end{array}$ & $\begin{array}{r}1.479 .78 \\
\pm 264.13\end{array}$ \\
\hline $\begin{array}{l}\text { Homogeneity afte } \\
\text { mechanical stress }\end{array}$ & $\mathrm{C}$ & $\mathrm{C}$ & $\mathrm{C}$ & $\mathrm{C}$ & $\mathrm{C}$ & $\mathrm{C}$ & $\mathrm{C}$ & $\mathrm{C}$ \\
\hline Consistency & C & $\mathrm{C}$ & C & C & C & $\mathrm{C}$ & $\mathrm{C}$ & $\mathrm{C}$ \\
\hline
\end{tabular}

BZ3=Benzophenone-3; OMC=Octylmethoxycinnamate; $\mathrm{CO} / \mathrm{OP}=\mathrm{Contro} /$ Opaque; $\mathrm{C}=$ In conformity

Table 6. Characteristics of the formulations containing water-soluble UVA-UVB sunscreen and anti-aging actives.

\begin{tabular}{|c|c|c|c|c|c|c|c|c|}
\hline \multirow{3}{*}{ Parameters } & \multicolumn{8}{|c|}{ Formulations } \\
\hline & \multicolumn{2}{|c|}{ Control } & \multicolumn{2}{|c|}{$\begin{array}{c}\text { Adenin }^{\circledR} \\
+\mathrm{BZ3}+\mathrm{OMC} \\
\end{array}$} & \multicolumn{2}{|c|}{$\begin{array}{c}\text { Biolumen }^{\circledR} \text { Firm } \\
+ \text { BZ3 + OMC }\end{array}$} & \multicolumn{2}{|c|}{$\begin{array}{c}\text { Coenzyme } \mathrm{Q}^{{ }^{\circledR} \mathrm{L}} \text {. } \\
+\mathrm{BZ3}+\mathrm{OMC}\end{array}$} \\
\hline & $\mathrm{t}_{0}$ & ${ }^{\mathrm{t}} 15_{\mathrm{d}}$ & $\mathrm{t}_{0}$ & ${ }^{\mathrm{t}} 15_{\mathrm{d}}$ & $\mathrm{t}_{0}$ & ${ }^{\mathrm{t}} 15_{\mathrm{d}}$ & $\mathrm{t}_{0}$ & ${ }^{\mathrm{t}} 15_{\mathrm{d}}$ \\
\hline Color & $\mathrm{CO} / \mathrm{OP}$ & $\mathrm{CO} / \mathrm{OP}$ & $\mathrm{CO} / \mathrm{OP}$ & $\mathrm{CO} / \mathrm{OP}$ & $\mathrm{CO} / \mathrm{OP}$ & $\mathrm{CO} / \mathrm{OP}$ & $\mathrm{CO} / \mathrm{OP}$ & $\mathrm{CO} / \mathrm{OP}$ \\
\hline Odor & C & C & C & C & C & C & C & C \\
\hline Homogeneity & $\mathrm{C}$ & $\mathrm{C}$ & $\mathrm{C}$ & $\mathrm{C}$ & $\mathrm{C}$ & $\mathrm{C}$ & $\mathrm{C}$ & $\mathrm{C}$ \\
\hline Brightness & $\mathrm{C}$ & $\mathrm{C}$ & $\mathrm{C}$ & $\mathrm{C}$ & $\mathrm{C}$ & $\mathrm{C}$ & $\mathrm{C}$ & $\mathrm{C}$ \\
\hline $\mathrm{pH}$ & 7.01 & 7.10 & 7.12 & 6.98 & 7.16 & 7.97 & 6.96 & 7.86 \\
\hline $\begin{array}{l}\text { Spreadability } \\
\qquad\left(\mathrm{mm}^{2}\right)\end{array}$ & $\begin{array}{c}1.385 .12 \\
\pm \\
53.67\end{array}$ & $\begin{array}{c}1.474 .75 \\
\pm \\
63.64\end{array}$ & $\begin{array}{l}1.499 .08 \\
+117.72\end{array}$ & $\begin{array}{r}2.787 .13 \\
+107.23\end{array}$ & $\begin{array}{r}1.476 .84 \\
+130.25\end{array}$ & $\begin{array}{l}3.399 .92 \\
\pm 110.04\end{array}$ & $\begin{array}{c}1.521 .32 \\
\pm \\
99.80\end{array}$ & $\begin{array}{c}3.630 .36 \\
\pm \\
87.16\end{array}$ \\
\hline $\begin{array}{l}\text { Homogeneity } \\
\text { after } \\
\text { mechanical } \\
\text { stress }\end{array}$ & $\mathrm{C}$ & $\mathrm{C}$ & $\mathrm{C}$ & $\mathrm{C}$ & $\mathrm{C}$ & $\mathrm{C}$ & $\mathrm{C}$ & $\mathrm{C}$ \\
\hline Consistency & $\mathrm{C}$ & $\mathrm{C}$ & $\mathrm{C}$ & $\mathrm{C}$ & $\mathrm{C}$ & $\mathrm{NC}$ & $\mathrm{C}$ & $\mathrm{NC}$ \\
\hline
\end{tabular}




\section{Discussion}

The results obtained demonstrated a reduction of the sun protection factor in the nonionic emulsion containing benzophenone 3 associated with octyl methoxycinnamate after the addition of the anti-aging actives Adenin ${ }^{\circledR}$ $(24,31)$ and Biolumen ${ }^{\circledR}$ Firm $(24,90)$, possibly due to interactions between filter components and the anti-aging actives.

Regarding the results of the determination of emulsions containing benzophenone-3 and octyl methoxycinnamate after the addition of anti-aging actives, it can be observed that the SPF had a low value, contrasting with what was expected due to its high concentration in the emulsion. Considering the anti-aging actives present in the nonionic emulsion containing the water-soluble UVAUVB filter, the SPF decreased even more, implicating the occurrence of an interaction between the actives and the sunscreen. The use of this filter, associated with the analyzed actives, to obtain effective sun protection, is not recommended.

These results are similar to those obtained by Alves et al. (2010). ${ }^{13}$ In their study, the in vitro variation of SPF in the tested emulsions was not significant after adding the anti-aging actives.

Alves et al. (2010) ${ }^{13}$ highlighted that it is necessary to consider the oily, aqueous, or emulsive character of the bases in which sunscreen are incorporated since theypresent different solubilities, causing interference in their absorptive properties. Therefore, the association of these filters with anti-aging actives should be done with caution, as reductions inthe SPF may occur.

Taking into account the characteristics of formulations containing benzophenone-3 + octylmethoxycinnamate and anti-aging actives, it was observed that the formulations presented satisfactory organoleptic characteristics, without phase separation, inferring stability of the emulsions. ThepH values in the formulations containing the anti-aging actives Adenin ${ }^{\circledR}$ and Coenzyme Q10 ${ }^{\circledR}$ Liposomes showed a slight increase after 15 days, althoughthe values obtained were close to those of the base emulsion (control). The emulsion containing Biolumen ${ }^{\circledR}$ Firm, in turn, showed a higher increment in $\mathrm{pH}$ value since the beginning of the study, with a slight increase at the end of 15 days. These differences in $\mathrm{pH}$ are 
probably related to the characteristics of the actives and the sunscreen.

The tests performed with the watersoluble UVA-UVB filter and the anti-aging actives showed several alterations after 15 days of testing, as described in Table 6. The $\mathrm{pH}$ values were increased in the formulations containing the actives Biolumen ${ }^{\circledR}$ Firm and Coenzyme Q10 ${ }^{\circledR}$ Liposomes, indicating possible formulationinstability.

Changes in consistency were observed in two actives, Biolumen ${ }^{\circledR}$ Firm and Coenzyme Q10 ${ }^{\circledR}$ Liposomes, possibly due to the interferences of the sunscreen with the antiaging actives and, probably, by the absorption of moisture by the emulsion. The remaining sensory tests continued stable throughout the time in which they were performed.

The spreadability results of the formulations in both tables demonstrated a significant increase. This is probably due to sudden changes in temperature to which the emulsions were submitted and also an indication that the packaging was not the most appropriate, as moisture absorption was present.

According to Moraes and Canuto (2011), ${ }^{18}$ some emulsion stability tests appear increased due to the incompatibility of the base raw materials with the actives used in their preparation, or to the packaging material, which allows light and oxygen to pass through. Intrinsic factors may also be related to emulsion instability, such as changes in $\mathrm{pH}$.

Meanwhile, according to Silva (2000), ${ }^{19}$ emulsions comprise more or less stable systems, especially when they are subjected to high temperatures, because the mean kinetic energy, rheological properties, and viscosity increase, also resulting in the chemical and physical instability of the emulsions.

Considering the study by Pinho et al. (2014), ${ }^{20}$ in which the in vitro SPF of gel-based magistral products containing the water-soluble UVA-UVB sunscreen was determined, the filter was effective when incorporated in emulsions with $\mathrm{pH} 7.2$ and 7.5. When below that, the filter may modify itself to acid form and, as a consequence, may no longer be water-soluble.

\section{Conclusion}

Under the experimental conditions of the present study, it was possible to observe that the most suitable sunscreen for the 
incorporation of anti-aging actives were benzophenone-3 and octylmethoxycinnamate since they obtained satisfactory results. This association in photoprotective cosmetic formulations is of substantial value, given both have contributed to and complement each other in protection against UV radiation damage and skin changes caused by extrinsic aging. Nevertheless, when analyzing their incorporation in water-soluble sunscreen emulsions, it was noted that, even at high concentrations, they were not able to determine a high SPF, suggesting their association with other filters.

Therefore, it is necessary that future studies determine the SPF of several formulations containing different anti-aging actives in order to verify if the product is able to guarantee its action.

\section{Referências}

1. Arizola HGA, Brescovici SM, Delgado SE, Ruschel CK. Modificações faciais em clientes submetidos a tratamento estético fonoaudiológico da face em clínica-escola de Fonoaudiologia. Rev CEFAC. 2012; 14(6):1167-1183.

2. Silva VN. Tratamento das rugas periorbiculares em idosos através da laserterapia $650 \mathrm{~nm}$ [trabalho de conclusão de curso]. Campina Grande: Universidade Estadual da Paraíba; 2013. 18 p.

3. Cabral LDS, Pereira SO, Partata AK. Filtros solares e fotoprotetores mais utilizados nas formulações no Brasil. Rev.CientITPAC. 2011; 4(3):01-10.

4. Schalka S, Steiner D. Fotoproteção no Brasil: Consenso brasileiro de fotoproteção. Recomendações da sociedade brasileira de dermatologia. 1. ed. Rio de Janeiro: Copyright; 2013.

5. Dutra EA. Filtros solares: determinação espectrofotométrica e cromatográfia [dissertação]. São Paulo: Universidade de São Paulo; 2000. 150 p.

6. Pharmanostra. Filtro solar UVA/B hidrossolúvel [accessed on Aug. 17, 2019]: Available from:

https://infinitypharma.com.br/uploads/insumos/ pdf/f/Filtro_UVA-B_hidrossoluvel.pdf

7. Tolotti MF. Protetores solares à base de filtros inorgânicos: desenvolvimento $\mathrm{e}$ caracterização [mestrado]. Guarapuava: Universidade Estadual do Centro Oeste; 2012. $124 \mathrm{p}$.

8. Limoeiro BC. O corpo em foco: envelhecimento e diferenças de gênero na cidade do Rio de Janeiro. RevTodavia. 2012;3(5):69-79.

9. Galena. Adenin: Renovador de Fibroblastos [accessed on Aug.17,2019]. Available from: https://docplayer.com.br/111383471-Adeninrenovador-de-fibroblastos-inci-namedenin.html

10. BiolumenFirm. Biotherafarmácia de manipulação[accessed on Aug.17,2019]. Available from:

https://biothera.com.br/biolumen-o-laser-emcreme

11. Mapric. LipossomasCoenzima Q10 [accessed on Aug.17,2019]. Available from: http://mapric.com.br/pdf/Boletim721_2806201 7-15h00.pdf

12. Mansur JS, Breder MNR, Mansur MCA, Azulay RD. Determinação do fator de proteção solar por espectrofotometria. An BrasDermatol. 1986; 61(3):121-124. 
13. Alves BL, Pereira JA, Ferreira RC, Gomes AJPS. Avaliação in vitro do fator de proteção solar a partir de fotoprotetores manipulados contendo agentes ativos antienvelhecimento. Colloq Vit. 2010; 2(2):50-56.

14. Anvisa - Agência Nacional de Vigilância Sanitária. Guia de Estabilidade de Produtos Cosméticos. 1. ed. Brasília: Anvisa; 2004.

15. Melo MRD. Desenvolvimento de uma loção fotoprotetora, avaliação da estabilidade e determinação in vitro do FPS.Perquirere. 2012; 9(1):81-97.

16. Lorca BSS. Desenvolvimento de formulação fotoprotetora contendo nanopartículas poliméricas com filtro solar [tese]. Rio de Janeiro: Universidade Federal do Rio de Janeiro; 2012. 153 p.

17. Zanin SMW, Miguel MD, Chimelli M, Dalmaz AC. Parâmetros físicos no estudo da estabilidade das emulsões Physicalsparameters in the emulsionstability study. Vis. Acad. 2001; $2(2): 47-58$.

18. Moraes IP, Canuto RFC. A importância da estabilidade em produtos cométicos [trabalho conclusão de curso]. Anápolis: Universidade Estadual de Goiás; 2011.53 p.

19. Silva FCF. Padronização de Métodos Analíticos para a Determinação de Filtros
Solares em Emulsões [dissertação]. São Paulo: Universidade de São Paulo; 2000. 121 p.

20. Pinho JJRG, Freitas TS, Pinho DJMR, Alves MS, Sousa OV. Determinação do fator proteção solar (in vitro) de produtos magistrais na forma de gel. Avaliação dos aspectos sensoriais e físico-químicos. HU Rev.2014; 40(1/2):81-88.

Reservado aos Editores

Data de submissão: 29/11/2020

Data de aprovação: 11/12/2020 